\title{
Prenatal and neonatal outcomes of pregnancies diagnosed with fetal single umbilical artery
}

\author{
Mehmet Obut ${ }^{1}$ (D) , Asya Kalaycı Öncü ${ }^{2}$ (D), Özge Yücel Çelik ${ }^{1}$ (D) , Arife Akay² (D), Güliz Özcan ${ }^{3}$ (D), \\ Gülşah Aynaoğlu Yıldız (iD, Can Tekin İskender ${ }^{1}$ (iD), Ali Turhan Çağlar ${ }^{1}$ \\ ${ }^{1}$ Department of Perinatology, Etlik Zübeyde Hanım Woman's Health Training and Research Hospital, Health Sciences University, Ankara, Turkey \\ 2Department of Gynecology and Obstetrics, Etlik Ziibeyde Hanım Woman's Health Training and Research Hospital, Health Sciences University, Ankara, Turkey \\ ${ }^{3}$ Department of Radiology, Etlik Ziibeyde Hanım Woman's Health Training and Research Hospital, Health Sciences University, Ankara, Turkey
}

\begin{abstract}
Objective: To investigate the associated anomalies and outcomes of fetuses diagnosed as having a single umbilical artery (SUA) which were reported inconsistently in previous studies.

Methods: The data of 82 pregnancies with fetal SUA, 35 of which were complex, and 47 isolated SUA (iSUA) and 100 pregnancies with fetal double umbilical arteries (DUA) between June 2018 and July 2020 were retrieved. We compared the maternal characteristics, and pregnancy and fetal outcomes of the three groups (iSUA, SUA, and DUA).

Results: Of 82 fetuses with SUA, 35 had 64 major structural abnormalities. 20 of these 35 fetuses $(57.1 \%)$ had cardiovascular malformations, $12(34.2 \%)$ had central nervous, 10 (28.5\%) had genitourinary, and eight (22.8\%) had gastrointestinal system malformations. Isolated SUA was present in SUA. Compared with the 100 DUA fetuses, SUA was a risk for intrauterine growth restriction (IUGR), preterm delivery, Apgar scores of $<7$, and admission to the neonatal intensive care unit. Having fetal chromosomal or structural abnormalities, was a risk for amnion fluid abnormality, pregnancy termination, intrauterine fetal death, early neonatal death, and a low live birth ratio in SUA cases.

Conclusion: SUA has an increased rate of fetal structural and chromosomal abnormalities. Among them, the most detected one is cardiac and the second most common one is central nervous system malformations. Pregnancies with fetal SUA have increased risk for IUGR, preterm delivery, low Apgar scores, and admission to the neonatal intensive care unit. The presence of additional structural or chromosomal malformations increases the rate of these adverse pregnancy risks. Thus, these cases warrant dedicated fetal ultrasonographic organ screening and close prenatal follow-up.
\end{abstract}

Keywords: Karyotypic abnormality, isolated single umbilical artery, prenatal ultrasonography, single umbilical artery, structural abnormalities.
Özet: Fetal tek umbilikal arter tanısı almış gebeliklerde prenatal ve neonatal sonuçlar

Amaç: Çalışmanın amacı, önceki çalışmalarda çelişkili şekilde bildirilmiş olan tek umbilikal arter (single umbilical artery, SUA) tanısı almış fetüslerin ilişkili anomalilerini ve sonuçlarını araştırmaktır.

Yöntem: Haziran 2018 ile Temmuz 2020 arasında, 35'i kompleks ve 47'si izole SUA (iSUA) olan fetal SUA'lı 82 gebenin ve fetal çift umbilikal arterli (double umbilical arteries, DUA) 100 gebenin verileri toplandı. Üç grubun (iSUA, SUA ve DUA) maternal özellikleri ile gebelik ve fetal sonuçları karşılaştırıldı.

Bulgular: SUA'lı 82 fetüsün $35^{\text {'inde }} 64$ majör yapısal anomali, bu 35 fetüsün 20'sinde (\%57.1) kardiyovasküler malformasyonlar, 12'sinde (\%34.2) merkezi sinir sistemi malformasyonları, 10'unda (\%28.5) genitoüriner sistem malformasyonları ve 8 'inde (\%22.8) gastrointestinal sistem malformasyonları mevcuttu. İzole SUA, SUA olguları içinde yer almaktaydı. DUA'lı 100 fetüs ile karşılaştırıldığında, SUA intrauterin büyüme kısıtllı̆ğı (IUGR), preterm doğum, 7'den küçük Apgar skorları ve yenidoğan yoğun bakım ünitesine yatış için bir risk oluşturmakta idi. SUA olgularında fetal kromozomal veya yapısal anomaliye sahip olmak; amniyotik sıvı anomalisi, gebeliğin sonlandırılması, intrauterin fetal ölüm, erken neonatal ölüm ve düşük canlı doğum oranı için risk faktörü idi.

Sonuç: SUA, artan bir oranda fetal yapısal ve kromozomal anomaliye sahiptir. Bunlar arasında en çok tespit edilen kardiyak malformasyonlar ve ikinci en yaygin olan ise merkezi sinir sistemi malformasyonlarıdır. Fetal SUA'lı gebelikler; IUGR, preterm doğum, düşük Apgar skorları ve yenidoğan yoğun bakım ünitesine yatış yönünden artmış riske sahiptir. Ek yapısal veya kromozomal malformasyon varlığı, bu advers gebelik risklerinin oranını artırmaktadır. Bu nedenle bu olgular, özel fetal ultrasonografik organ taramasına ve yakın prenatal takibe gereksinim duymaktadır.

Anahtar sözcükler: Karyotipik anomali, izole tek umbilikal arter, prenatal ultrasonografi, tek umbilikal arter, yapısal anomaliler.

Correspondence: Mehmet Obut, MD. Department of Perinatology, Etlik Zübeyde Hanım Woman's Health Training and Research Hospital, Health Sciences University, Ankara, Turkey. e-mail: drmehmetobut@hotmail.com / Received: September 29, 2021; Accepted: November 7, 2021

How to cite this article: Obut M, Kalaycı Öncü A, Yücel Çelik Ö, Akay A, Özcan G, Aynaoğlu Yıldız G, İskender CT, Çağlar AT. Prenatal and neonatal outcomes of pregnancies diagnosed with fetal single umbilical artery. Perinatal Journal 2021;29(3):217-224. doi:10.2399/prn.21.0293007

ORCID ID: M. Obut 0000-0002-6925-4784; A. Kalaycı Öncü 0000-0001-8582-6175; Ö. Yücel Çelik 0000-0002-7746-1943; 


\section{Introduction}

Single umbilical artery (SUA) is one of the most common abnormalities detected prenatally. Its prevalence varies, ranging from $0.2 \%$ to $2 \%$, depending on the study population and gestational weeks at the ultrasonographic examination. It is more common in Caucasians than in any other races and increases with advancing gestational weeks. Its prevalence is higher in multifetal gestations than in singleton pregnancies. ${ }^{[1]}$ Environmental, genetic, and hemodynamic disturbances in the first weeks of gestation have been blamed as factors in the etiology of SUA because it is more common among pregnancies of mothers who smoke, and those with hypertension, twins, and siblings. ${ }^{[1,2]}$

Three main theories have been proposed to explain the pathogenesis of SUA: primary agenesis and secondary atresia/atrophy of one of two umbilical arteries (UMA), and persistence of the allantoic artery of the body stalk. Of these theories, the most accepted is the theory of secondary atrophy/atresia because in some cases of SUA there are two UMAs displayed in ultrasonography (USG) findings in early gestational weeks. ${ }^{[3]}$

The presence of SUA has been accepted as a soft marker for fetal congenital structural and chromosomal abnormalities. ${ }^{[1,46]}$ Although there are many case reports or small case series in the literature, most large-scale studies date back at least 7 years, and many are at least 10 years old. Indeed, two metanalyses comprising seven studies (three cohort and four case-control studies) and 11 studies (nine cohort and two case-control studies), respectively, were able to identify its relation with congenital structural and chromosomal abnormalities. In more than half of the studies included in the first metanalysis, fetal karyotyping was not reported. In the more recent metanalysis, the rate of abnormal karyotype was not reported. Therefore, the data on the incidence of abnormal karyotypes are relatively scarce. Moreover, fetal abnormalities can be picked up more easily with higher quality USG machines, better conceptualized sonographic examinations (neuro sonography and cardiac screening), and the availability of chromosome microarray analysis. ${ }^{[7,8]}$

There is a discrepancy between the reported frequencies of adverse pregnancy outcomes in studies comparing SUA and DUA cases. ${ }^{[5,7,-16]}$ For example, compared with DUA, some studies reported higher rates of IUGR, ${ }^{[5,10,11]}$ preterm delivery, ${ }^{[9,10]}$ and lower 1-minute and 5-minute Apgar scores, ${ }^{[15]}$ whereas others reported similar rates of IUGR, ${ }^{[12,13]}$ preterm delivery, ${ }^{[14]}$ and 1-minute and 5-minute Apgar scores. ${ }^{[16]}$ Many studies reporting accompanying structural malformations in SUA cases pointed out affected organs rather than exact abnormalities. ${ }^{[1,2,5]}$ In addition, there is a scarcity of studies evaluating the outcomes of SUA with additional structural and chromosomal malformations. Therefore, to provide a better basis for counselling affected pregnant women, it is clear that further studies are needed.

In the present study, we aimed to evaluate chromosomal and structural abnormalities, maternal characteristics, and fetal outcomes of cases of SUA by comparing fetuses with isolated SUA (iSUA), complex SUA, and DUA (control group).

\section{Methods}

We conducted a retrospective study by evaluating cases of SUA diagnosed between June 2018 and July 2020. The Institutional Review Board (IRB) of Etlik Zübeyde Hanım Women's Health and Training Hospital approved the study (IRB \#21-05). For the study, the data of cases of SUA were retrieved from the hospital database. To compare cases of SUA with controls, the data of 100 age-matched pregnancies with fetal DUA were selected. The cases of SUA were grouped as isolated SUA (iSUA) and complex SUA depending on the presence of structural abnormalities. Isolated SUA was determined as SUA without structural or chromosomal abnormalities.

Gestational age was calculated according to the first day of the last menstrual period (LMP) and crown-rump length revealed in the first-trimester USG examination. If there were seven or more days between dating according to the LMP and first-trimester USG, the gestational age was corrected according to first-trimester USG.

When the death of a fetus occurred at $\leq 23$ gestational weeks, the death was classified as intrauterine fetal demise (IUFD), and those dying in-utero at $\geq 24$ gestational weeks were classified as stillbirths. Intrapartum fetal death is defined as the death of an infant after the onset of labor but before they are born. Pregnancy termination refers to elective abortions due to major fetal structural or chromosomal abnormalities.

IUGR was determined as estimated fetal weight (EFW) of $<3$ rd percentile based on sonographic measurements of the fetal biparietal diameter, head circum- 
ference, abdomen circumference, and femur length. ${ }^{[17]}$ To eliminate confounding factors, multifetal pregnancies were excluded.

Delivery between the 24th and 37th gestational weeks was defined as preterm delivery regardless of fetal viability. Amnion fluid was evaluated based on single deepest vertical pocket measurements, which when less than $2 \mathrm{~cm}$ was diagnosed as oligohydramnios, between 2 and $8 \mathrm{~cm}$ as normal, and above $8 \mathrm{~cm}$ as polyhydramnios.

According to our clinical protocol, after SUA was diagnosed in a detailed fetal anatomic USG, screening was performed by an experienced perinatologist. The device used was a Voluson E6 equipped with $5-9-\mathrm{MHz}$ volumetric transvaginal transducers and a $4-8-\mathrm{MHz}$ volumetric convex abdominal transducer, (GE Medical Systems, Horten, Norway). For pregnancies in the first trimester or those with poor image quality due to obesity, transvaginal USG screening was performed in adjunct to abdominal USG screening. The diagnosis of SUA was made from either a color Doppler view of the umbilical arteries on both bladder wall sides or by displaying a cross-section of the umbilical cord loop. All patients with SUA were screened using fetal echocardiography. Amniocentesis with chromosome analysis was offered to all parents with fetal SUA. Chromosomal microarray analysis was made in patients with SUA with additional structural malformations who consented.

Routine prenatal care was offered to patients with iSUA. For patients diagnosed as having complex SUA, special prenatal care depended on accompanying structural or karyotypic abnormality. These couples were counseled in detail about prognosis, and pregnancy termination was offered when it was thought there was a poor prognosis.

The demographic characteristics of the pregnant women including age, body mass index (BMI), smoking status, parity, maternal chronic disease were collected at the time of the examination and noted. The course and outcomes of pregnancies with SUA including amnion fluid abnormalities, IUGR, preeclampsia, and fetal 1minute and 5-minute Apgar scores, pregnancy termination, intrapartum fetal death, preterm delivery, admission to the neonatal intensive care unit (NICU), and early neonatal death were also noted.

\section{Statistical analysis}

The SPSS statistics software version 21 (IBM, Armonk, NY, USA) was used for evaluating the data. The results of patients stratified as having iSUA and complex SUA and controls (DUA) were compared. The normality of continuous variables was assessed using the KolmogorovSmirnov test and histograms. One-way analysis of variance (ANOVA) was used for independent samples with normal distribution, and the Kruskal-Wallis test was used for samples that were not normally distributed. P-values $<0.05$ were accepted as statistically significant. Bonferroni correction was used for statistical significance.

\section{Results}

During the study period, a total of 82 pregnancies were diagnosed as having fetal SUA. Of those, 35 (42.68\%) had at least one structural or chromosomal abnormality and $47(57.32 \%)$ were iSUA. There were no significant differences in maternal characteristics between the complex and iSUA and DUA groups regarding maternal age, parity, BMI, smoking status, nationality, preeclampsia, and maternal chronic diseases. The mean gestational weeks at diagnosis of complex SUA was earlier than in iSUA cases $(14.2 \pm 3.1$ vs. $20.4 \pm 5.7$ weeks, $\mathrm{p}<0.001)$. Amnion fluid abnormalities were more common in the complex SUA group than in the iSUA and DUA groups $(\mathrm{p}<0.05)$, but there was no difference between the iSUA and DUA controls $(\mathrm{p}>0.05)$. Nine $(25.7 \%)$ patients in the SUA group had IUGR, 10 (21.2\%) in the iSUA group had IUGR, and four (4.0\%) in the DUA controls had IUGR; the incidence of IUGR in the SUA and iSUA groups was similar $(\mathrm{p}>0.05)$, but both were higher than in DUA controls ( $\mathrm{p}=0.01)$ (Table 1).

Table 2 demonstrates the comparisons of fetal outcomes in the iSUA, complex SUA and DUA groups. SUA was a risk factor for Apgar scores of $<7$ and NICU need, and the presence of concomitant additional structural and chromosomal abnormalities further increased these risks. In other words, the incidence of Apgar scores of $<7$ and NICU need was SUA $>$ iSUA $>$ DUA $(p<0.001)$. Fourteen $(50 \%)$ patients in the SUA group had preterm deliveries, $13(30.2 \%)$ in the iSUA group had preterm deliveries, and $11(11.2 \%)$ patients among the DUA controls had preterm deliveries. The incidence of preterm delivery in the SUA and iSUA groups were similar; however, both were higher than the DUA controls ( $<<0.001$ ). Although there were no differences between the iSUA and control groups regarding to intrauterine fetal death and early neonatal death, these were significantly higher in the complex SUA group $(\mathrm{p}<0.05)$. The iSUA group 
Table 1. Maternal characteristics and pregnancy-related parameters.

\begin{tabular}{|c|c|c|c|c|c|}
\hline \multicolumn{2}{|l|}{ Variables } & $\begin{array}{c}\text { Complex SUA } \\
n=35(\%)\end{array}$ & $\begin{array}{c}\text { Isolated SUA } \\
n=47(\%)\end{array}$ & $\begin{array}{c}\text { DUA } \\
\mathrm{n}=100(\%)\end{array}$ & p-value \\
\hline \multicolumn{2}{|c|}{ Maternal age (years) } & $28.4 \pm 5.9$ & $28.2 \pm 6.4$ & $28.8 \pm 4.9$ & 0.830 \\
\hline \multicolumn{2}{|c|}{ Maternal BMI $\left(\mathrm{kg} / \mathrm{m}^{2}\right)$} & $25(21-34)$ & $25(20-38)$ & $25(19-44)$ & 0.743 \\
\hline \multicolumn{2}{|c|}{ Smoking } & $4(11.4)$ & $4(8.5)$ & $2(2.0)$ & 0.062 \\
\hline \multirow[t]{2}{*}{ Nationality } & Turkey & $32(91.4)$ & $43(91.5)$ & $91(91.0)$ & \multirow{2}{*}{0.994} \\
\hline & Syria & $3(8.6)$ & $4(8.5)$ & $9(9.0)$ & \\
\hline \multicolumn{2}{|l|}{ Maternal disease } & $1(2.9)$ & $5(10.6)$ & $10(1.0)$ & 0.383 \\
\hline \multicolumn{2}{|l|}{ IUGR } & $9(25.7)^{*}$ & $10(21.2)^{*}$ & $4(4.0)^{t, \neq}$ & 0.01 \\
\hline \multicolumn{2}{|l|}{ Preeclampsia } & $1(2.8)$ & $2(4.3)$ & $3(3.0)$ & 0.912 \\
\hline \multirow[t]{3}{*}{ Amniotic fluid } & Reduced & $6(17.1)^{*}$ & $5(10.6)$ & $4(4.0)^{\ddagger}$ & 0.041 \\
\hline & Normal & $25(71.5)^{\star}$ & $39(83.0)$ & $95(95.0)^{\ddagger}$ & 0.001 \\
\hline & Increased & $4(11.4)^{*}$ & $3(6.4)$ & $1(1.0)^{\ddagger}$ & 0.026 \\
\hline \multirow[t]{2}{*}{ Parite } & Multiparous & $21(60.0)$ & $28(59.5)$ & $64(64)$ & 0.841 \\
\hline & Nulliparous & $14(40.0)$ & $19(40.5)$ & $36(36)$ & 0.904 \\
\hline
\end{tabular}

*Different from DUA cases; ${ }^{\dagger}$ different from isolated cases; ${ }^{\ddagger}$ different from complex cases. BMI: body mass index; DUA: double umbilical artery; IUGR: intrauterine growth restriction; SUA: single umbilical artery.

was not different from the DUA control group in respect to pregnancy terminations; however, seven pregnancies were terminated due to major fetal structural and chromosomal anomalies in the complex group, which was statistically higher than in the iSUA and DUA control groups $(\mathrm{p}<0.05)$.

A total of 64 major structural malformations were detected in 35 fetuses. Of these 35 fetuses, 20 (57.1\%) had cardiac malformations, 12 (34.2\%) had central nervous system malformations, $10(28.5 \%)$ had genitourinary malformations, $8(22.8 \%)$ had gastrointestinal malformations, and $5(14.2 \%)$ had musculoskeletal system malformations. There was a single anomaly in 18 fetuses, two anomalies in eight fetuses, and three or more in nine fetuses. Among the 64 detected structural malformations, the most common ones were cardiac malformations

Table 2. Fetal and neonatal outcomes.

\begin{tabular}{|c|c|c|c|c|c|}
\hline \multicolumn{2}{|c|}{ Variables } & $\begin{array}{c}\text { Complex SUA } \\
n=35(\%)\end{array}$ & $\begin{array}{c}\text { Isolated SUA } \\
n=47(\%)\end{array}$ & $\begin{array}{c}\text { DUA } \\
\mathrm{n}=100(\%)\end{array}$ & p-value \\
\hline \multicolumn{2}{|c|}{ Live birth } & $20(57.1)^{*,+}$ & $43(91,4)^{\ddagger}$ & $98(100)^{\ddagger}$ & $<0.001$ \\
\hline \multicolumn{2}{|c|}{ Apgar score (1-minute) } & $8.5(0-9)^{*,+}$ & $9(0-9)^{\ddagger}$ & $9(5-9)^{\ddagger}$ & $<0.001$ \\
\hline \multicolumn{2}{|c|}{ Apgar score (5-minute) } & $9.5(0-10)^{*,+}$ & $10(0-10)^{\ddagger}$ & $10(6-10)^{\ddagger}$ & $<0.001$ \\
\hline \multicolumn{2}{|c|}{ Apgar score $<7$} & $7(20)^{*,+}$ & $4(8.6)^{*, \neq}$ & $2(2)^{t, \neq}$ & $<0.001$ \\
\hline \multicolumn{2}{|l|}{ Stillbirth } & $3(8.5)^{*}$ & $1(2.1)$ & $0(0)^{\ddagger}$ & 0.012 \\
\hline \multicolumn{2}{|c|}{ Early neonatal death } & $3(8.5)^{*}$ & $1(2.1)$ & $0(0)^{\ddagger}$ & 0.012 \\
\hline \multicolumn{2}{|c|}{ Intrapartum fetal death } & $2(5.7)^{*}$ & $1(2.1)$ & $0(0)^{\ddagger}$ & 0.070 \\
\hline \multicolumn{2}{|c|}{ IUFD $(>20 \mathrm{w}, \leq 23 \mathrm{w})$} & $1(2.9)$ & $2(4.3)$ & $2(2)$ & 0.737 \\
\hline \multicolumn{2}{|c|}{ Pregnancy termination } & $9(25.8)^{*,+}$ & $0(0)^{\ddagger}$ & $0(0)^{\ddagger}$ & $<0.001$ \\
\hline \multicolumn{2}{|c|}{ Preterm delivery } & $14 / 25(50)^{*}$ & $13 / 45(30.2)^{*}$ & $11 / 98(11.2)^{\dagger, \ddagger}$ & $<0.001$ \\
\hline \multicolumn{2}{|c|}{ Admission to NICU } & $14 / 20(70)^{*,+}$ & $10 / 43(23.2)^{*, \pm}$ & $3 / 98(3)^{t, \neq}$ & $<0.001$ \\
\hline \multirow[t]{2}{*}{ Gender } & Female & $20(57)$ & $22(47)$ & $51(51)$ & 0.651 \\
\hline & Male & $15(43)$ & $25(53)$ & $49(49)$ & \\
\hline
\end{tabular}

*Different from DUA cases; †different from isolated cases; ₹different from complex cases. DUA: double umbilical artery; IUFD: intrauterine fetal death; NICU: neonatal intensive care unit; SUA: single umbilical artery; w: weeks. 
$(\mathrm{n}=23,35.9 \%)$, followed by central nervous system malformations $(\mathrm{n}=15,23.5 \%)$, gastrointestinal malformations ( $\mathrm{n}=7,10.9 \%)$, and genitourinary system malformations $(\mathrm{n}=6,9.4 \%)$. The most detected cardiovascular anomaly was hypoplastic left heart. Table 3 shows fetal structural anomalies detected in patients with SUA.

A total of 42 patients, of which consisting of thirtyfive patients with complex SUA and seven with iSUA, underwent amniocentesis with chromosomal analysis. There were no karyotypic abnormalities in patients with iSUA, neither prenatally nor postnatally. Among patients with complex SUA five had karyotypic abnormalities: trisomy $13(\mathrm{n}=2)$, trisomy $18(\mathrm{n}=1)$, and Turner $(\mathrm{n}=1)$ and DiGeorge syndrome $(\mathrm{n}=1)$.

We also noted other soft markers present along with SUA, which were hyperechogenic bowel in 14 cases, cardiac hyperechogenic focus in four cases, short femur and humerus in one case, and hypoplastic nasal bone in one case.

\section{Discussion}

We found that the SUA even in the absence of other anomalies posed risks for adverse prenatal outcomes including IUGR, Apgar scores of $<7$, preterm delivery, and admission to the NICU $(\mathrm{p}<0.05)$. In addition to risks with iSUA, the presence of concomitant fetal structural or chromosomal anomalies increased the risks of amnion fluid abnormalities, intrauterine fetal death, early neonatal death, and pregnancy termination, and further increased risks of Apgar scores of $<7$ and admission to the NICU $(\mathrm{p}<0.05)$.

In this study, $42.6 \%(35 / 82)$ of the patients with SUA had at least one structural abnormality. Similarly, in the literature, the reported frequency of additional abnormalities with SUA varies, ranging between $13-50 \% \cdot{ }^{[2,10,18]}$ Besides the effect of race and gestational weeks in fetal USG evaluations, one explanation for this high variability in accompanying fetal structural abnormalities may be the characteristics of the center at which the study was performed. We think that there is a high possibility that patients with complicated SUA including those with fetal structural or karyotypic abnormalities and IUGR are referred to tertiary centers. In line with our opinion, population-based studies $^{[10]}$ reported lower additional structural defects than those conducted in referral centers. ${ }^{[2,18]}$ However, even in population-based studies, the reported frequency of
Table 3. Structural malformations by the organ systems involved in 82 fetuses with SUA (35 fetuses with at least one structural malformation).

\begin{tabular}{|c|c|}
\hline Organ systems & Total $(n=64)$ \\
\hline Cardiovascular system & $23(35.9 \%)$ \\
\hline Truncus arteriosus & 2 \\
\hline Anomalous pulmonary venous return & 1 \\
\hline Dextrocardia & 2 \\
\hline Hypoplastic left heart & 4 \\
\hline Coarctation of aorta & 1 \\
\hline Ectopia cordis & 1 \\
\hline Double outlet right ventricle & 2 \\
\hline Pericardial effusion & 2 \\
\hline Pulmonary artery-right ventricular hypoplasia & 1 \\
\hline Tetralogy of Fallot & 1 \\
\hline Right atrium dilatation & 1 \\
\hline Septal aneurysm & 1 \\
\hline Ventricular septal defect & 3 \\
\hline Transposition of great arteries & 1 \\
\hline Central nervous system & $15(23.5 \%)$ \\
\hline Ventriculomegaly & 4 \\
\hline Iniencephaly & 1 \\
\hline Lemon sign & 2 \\
\hline Neural tube defects & 2 \\
\hline Rhombencephalosynapsis & 1 \\
\hline Corpus callosum agenesis (partial) & 1 \\
\hline Cystic hygroma & 2 \\
\hline Cephalocele & 1 \\
\hline Cerebellar cyst & 1 \\
\hline Gastrointestinal system & $7(10.9 \%)$ \\
\hline Diaphragmatic hernia & 2 \\
\hline Cleft lip/palate & 1 \\
\hline Omphalocele & 2 \\
\hline Gallbladder aplasia & 1 \\
\hline Avascular body in liver & 1 \\
\hline Genitourinary system & $6(9.4 \%)$ \\
\hline Multicystic dysplastic kidney (bilateral) & 4 \\
\hline Renal agenesis & 2 \\
\hline Musculoskeletal system & $5(7.8 \%)$ \\
\hline Skeletal dysplasia & 1 \\
\hline Sirenomelia & 1 \\
\hline Scoliosis & 1 \\
\hline Rocker bottom feet & 1 \\
\hline Club foot & 1 \\
\hline Others & $8(12.5 \%)$ \\
\hline Hydrops fetalis & 1 \\
\hline Thymus hypoplasia & 2 \\
\hline Thorax hypoplasia & 1 \\
\hline Jugular cyst & 1 \\
\hline Umbilical cord aneurysm & 2 \\
\hline Ocular coloboma & 1 \\
\hline
\end{tabular}

additional structural and chromosomal abnormalities in cases of SUA were much more common than in patients without SUA, thus fetuses with SUA warrant a detailed fetal ultrasonographic evaluation and genetic testing, especially those with SUA with additional structural defects. ${ }^{[4]}$ 
With advancing imaging quality of USG, SUA can be diagnosed as early as the 11th gestational week by displaying the absence of one of the two umbilical arteries on the bladder wall side or a cross-section of the free umbilical cord. ${ }^{[19]}$ Diagnosing these cases in earlier gestational weeks has the potential to change the frequency of detecting additional anomalies with SUA. For example, most renal and gastrointestinal abnormalities cannot be detected before certain gestational weeks because amnion fluid in early gestational weeks is not dependent on fetal urination and physiologic gut herniation before 12 gestational weeks. ${ }^{[20,21]} \mathrm{In}$ the current study, most of the SUA cases were diagnosed in the second trimester; however, complex SUA cases were detected in earlier gestational weeks than iSUA $(\mathrm{p}<0.001)$. This may result from the fact that when a structural or chromosomal abnormality is detected, the patient is subject to more detailed fetal anatomic screening, which heightens the possibility of detecting SUA. Unlike previous studies which found genitourinary or gastrointestinal system anomalies as the second most common anomaly, ${ }^{[10,22]}$ we found fetal central nervous system anomalies as the second most frequent group of anomalies. Similar to previous studies, in this study, cardiac anomalies were the most commonly detected abnormalities $(24.3 \%, 20 / 82) .^{[2,5,18]}$ Wang et al. evaluated 152 singleton pregnancies and found that the frequency of cardiac anomalies with SUA was $12.5 \%$, and the most common cardiac anomalies were hypoplastic left heart syndrome (HLHS), single ventricle, and double-outlet right ventricle (DORV) ${ }^{[18]}$ This is in line with our study because we found the most common fetal cardiac anomalies as HLHS, ventricular septal defect, and DORV. There were karyotypic abnormalities in five $(6.1 \%)$ patients with SUA. The frequency of detected karyotypic abnormalities revealed in this study is comparable with other studies, which ranged from $1.3 \%$ to $15.3 \% .^{[10,22-25]}$ However, the number of our patients who consented to genetic tests was relatively low, which may not reflect the true percentages of genetic abnormalities. Similar to previous studies, there were no karyotypic abnormalities in patients with iSUA. ${ }^{[5]}$ There were 14 patients with at least one soft marker including hyperechogenic bowel, intraventricular bright focus, nasal hypoplasia, and short femur and humerus in the iSUA group; however, the presence of these soft markers along with iSUA has not increased karyotyping abnormalities of patients with iSUA.

How prenatal care should be given in pregnancies with SUA is a matter of debate. Although there are studies that found normal development in fetuses with SUA and recommended standard prenatal care, ${ }^{[2,26]}$ most studies found an impairment in development with SUA and suggested intervallic biometric measurements and Doppler evaluations for the timely discovery of possible IUGR. ${ }^{[1,2,5,7,10,27]}$ We would support the latter because the frequency of IUGR were $25.7 \%$ $(9 / 35)$ in SUA, $21.2 \%(10 / 47)$ in iSUA vs. $4 \%(4 / 98)$ in the DUA controls. The possible mechanism of IUGR in iSUA was explained by the reduction of cytoplasmic mass resulting from malnutrition. Considering patients with complex SUA, there is another contributing factor, in addition to cytoplasmic mass reduction, which is total cell reduction. ${ }^{[28]}$ Although there is consensus that the presence of complex SUA increases the incidence of preterm delivery, but this relation in iSUA remains a dilemma. ${ }^{[10,11,27,29]}$ The current study showed that along with SUA, iSUA was a risk for preterm delivery. Although most preterm deliveries were due to iatrogenic deliveries related to IUGR, there were other contributing factors including preterm premature rupture of membranes and preterm labor. The frequency of other adverse pregnancy outcomes including fetal Apgar scores of $<7$ and admission to the NICU were higher in the SUA group compared with the DUA controls, which is in agreement with previous studies. $^{[1,7]}$

Consistent with our study, many studies showed that the presence of additional or chromosomal abnormalities in patients with SUA increased the frequency of adverse pregnancy outcomes including amnion fluid abnormalities, intrauterine fetal death, death after birth, and pregnancy termination. ${ }^{[5,10]}$ Therefore, we think that the prenatal care of these fetuses must be specified considering the type of accompanying abnormality.

A limitation of the study was that this cohort was from a tertiary referral center, which may have overrepresented patients with abnormalities or pregnancies complicated by IUGR, amnion fluid abnormalities or preterm labor, which may not reflect the true ratios. Fetal cardiac echography was performed in all patients, but the majority were in the early gestational weeks, which were not optimal for fetal cardiac evaluation. 


\section{Conclusion}

Cardiac anomalies were the most detected anomalies in patients with SUA, followed by anomalies affecting the central nervous system. The frequencies of adverse outcomes including IUGR, Apgar scores of $<7$, and admission to the NICU were higher in the SUA group compared with DUA controls. The presence of accompanying fetal structural or chromosomal anomalies with SUA increases the risks of pregnancy termination, amnion fluid abnormalities, intrauterine fetal death, fetal death after delivery, preterm delivery, and further increases the risks for Apgar scores of $<7$ and admission to the NICU. Thus, fetuses with SUA warrant detailed ultrasonographic fetal anatomic screening and close prenatal follow-up.

Funding: This work did not receive any specific grant from funding agencies in the public, commercial, or not-for-profit sectors.

Compliance with Ethical Standards: The authors stated that the standards regarding research and publication ethics, the Personal Data Protection Law and the copyright regulations applicable to intellectual and artistic works are complied with and there is no conflict of interest.

\section{References}

1. Murphy-Kaulbeck L, Dodds L, Joseph KS, Van den Hof M. Single umbilical artery risk factors and pregnancy outcomes. Obstet Gynecol 2010;116:843-50. [PubMed] [CrossRef]

2. Hua M, Odibo AO, Macones GA, Roehl KA, Crane JP, Cahill AG. Single umbilical artery and its associated findings. Obstet Gynecol 2010;115:930-4. [PubMed] [CrossRef]

3. Persutte WH, Hobbins J. Single umbilical artery: a clinical enigma in modern prenatal diagnosis. Ultrasound Obstet Gynecol 1995;6:216-29. [PubMed] [CrossRef]

4. Van den Hof MC, Wilson RD; Diagnostic Imaging Committee, Society of Obstetricians and Gynaecologists of Canada; Genetics Committee, Society of Obstetricians and Gynaecologists of Canada. Fetal soft markers in obstetric ultrasound. J Obstet Gynaecol Can 2005;27:592-636. [PubMed] [CrossRef]

5. Li TG, Wang G, Xie F, Yao JM, Yang L, Wang ML, et al. Prenatal diagnosis of single umbilical artery and postpartum outcome. Eur J Obstet Gynecol Reprod Biol 2020;254:6-10. [PubMed] [CrossRef]

6. Malova J, Bohmer D, Luha J, Pastorakova A, Cierna Z, Braxatorisova T. Single umbilical artery and reproduction losses in Slovak population: relation to karyotype and fetal anomalies. Bratisl Lek Listy 2018;119:330-4. [PubMed] [CrossRef]

7. Kim HJ, Kim JH, Chay DB, Park JH, Kim MA. Association of isolated single umbilical artery with perinatal outcomes: systemic review and meta-analysis. Obstet Gynecol Sci 2017;60: 266-73. [PubMed] [CrossRef]
8. Voskamp BJ, Fleurke-Rozema H, Oude-Rengerink K, Snijders RJM, Bilardo CM, Mol BW, et al. Relationship of isolated single umbilical artery to fetal growth, aneuploidy and perinatal mortality: systematic review and meta-analysis. Ultrasound Obstet Gynecol 2013;42:622-8. [PubMed] [CrossRef]

9. Luo X, Zhai S, Shi N, Li M, Cui S, Xu Y, et al. The risk factors and neonatal outcomes of isolated single umbilical artery in singleton pregnancy: a meta-analysis. Sci Rep 2017;7:7396. [PubMed] [CrossRef]

10. Friebe-Hoffmann U, Hiltmann A, Friedl TWP, Lato K, Hammer R, Janni W, et al. Prenatally diagnosed single umbilical artery (SUA) - Retrospective analysis of 1169 fetuses. Ultraschall Med 2019;40:221-9. [PubMed] [CrossRef]

11. Naveiro-Fuentes M, Carrillo-Badillo MP, Malde-Conde J, Gallo-Vallejo JL, Puertas-Prieto A. Perinatal outcomes in singleton pregnancies with a single umbilical artery. J Matern Fetal Neonatal Med 2016;29:1562-5. [PubMed] [CrossRef]

12. Caldas LM, Liao A, Carvalho MH, Francisco RP, Zugaib M. Should fetal growth be a matter of concern in isolated single umbilical artery? Rev Assoc Med Bras (1992) 2014;60:125-30. [PubMed] [CrossRef]

13. Predanic M, Perni SC, Friedman A, Chervenak FA, Chasen ST. Fetal growth assessment and neonatal birth weight in fetuses with an isolated single umbilical artery. Obstet Gynecol 2005;105:1093-7. [PubMed] [CrossRef]

14. Battarbee AN, Palatnik A, Ernst LM, Grobman WA. Association of isolated single umbilical artery with small for gestational age and preterm birth. Obstet Gynecol 2015;126: 760-4. [PubMed] [CrossRef]

15. Gutvirtz G, Walfisch A, Beharier O, Sheiner E. Isolated single umbilical artery is an independent risk factor for perinatal mortality and adverse outcomes in term neonates. Arch Gynecol Obstet 2016;294:931-5. [PubMed] [CrossRef]

16. Shen N, Zhang W, Li G. Impact of isolated single umbilical artery on pregnancy outcome and delivery in full-term births. J Obstet Gynaecol Res 2016;42:399-403. [PubMed] [CrossRef]

17. Oğlak SC, Bademkıran MH, Obut $M$. Predictor variables in the success of slow-release dinoprostone used for cervical ripening in intrauterine growth restriction pregnancies. J Gynecol Obstet Hum Reprod 2020;49:101739. [PubMed] [CrossRef]

18. DeFigueiredo D, Dagklis T, Zidere V, Allan L, Nicolaides $\mathrm{KH}$. Isolated single umbilical artery: need for specialist fetal echocardiography? Ultrasound Obstet Gynecol 2010;36:5535. [PubMed] [CrossRef]

19. Trecet J. Ultrasound screening in the second trimester. In: Diaz Recasens J, editor. Prenatal diagnosis. Madrid: Ergon Editorial; 2010. p. 135-225.

20. Dias T, Sairam S, Kumarasiri S. Ultrasound diagnosis of fetal renal abnormalities. Best Pract Res Clin Obstet Gynaecol 2014;28:403-15. [PubMed] [CrossRef]

21. Badillo AT, Hedrick HL, Wilson RD, Danzer E, Bebbington MW, Johnson MP, et al. Prenatal ultrasonographic gastrointestinal abnormalities in fetuses with gastroschisis do not correlate with postnatal outcomes. J Pediatr Surg 2008;43:647-53. [PubMed] [CrossRef] 
22. Wang J, Ye Y, Xin T, Zhang X, Chen S, Wu Y, et al. Is echocardiography necessary for all single umbilical artery fetuses? A retrospective study in a selected Chinese population. J Obstet Gynaecol Res 2019;45:803-9. [PubMed] [CrossRef]

23. Granese R, Coco C, Jeanty P. The value of single umbilical artery in the prediction of fetal aneuploidy: findings in 12,672 pregnant women. Ultrasound Q 2007;23:117-21. [PubMed] [CrossRef]

24. Ebbing C, Kessler J, Moster D, Rasmussen S. Single umbilical artery and risk of congenital malformation: population-based study in Norway. Ultrasound Obstet Gynecol 2020;55:510-5. [PubMed] [CrossRef]

25. Khong TY, George K. Chromosomal abnormalities associated with a single umbilical artery. Prenat Diagn 1992;12:965-8. [PubMed] [CrossRef]
26. Burshtein S, Levy A, Holcberg G, Zlotnik A, Sheiner E. Is single umbilical artery an independent risk factor for perinatal mortality? Arch Gynecol Obstet 2011;283:191-4. [PubMed] [CrossRef]

27. Baser E, Celik IH, Bilge M, Kasapoglu T, Isik DU, Yalvac ES, et al. Abnormal umblical artery Doppler is utilized for fetuses with intrauterine growth restriction birth at $280 / 7-336 / 7$ gestational weeks. Fetal Pediatr Pathol 2020;39:467-75. [PubMed] [CrossRef]

28. Heifetz SA. Single umbilical artery. A statistical analysis of 237 autopsy cases and review of the literature. Perspect Pediatr Pathol 1984;8:345-78. [PubMed]

29. Mailath-Pokorny M, Worda K, Schmid M, Polterauer S, Bettelheim D. Isolated single umbilical artery: evaluating the risk of adverse pregnancy outcome. Eur J Obstet Gynecol Reprod Biol 2015;184:80-3. [PubMed] [CrossRef]

This work is licensed under the Creative Commons Attribution-NonCommercial-NoDerivs 4.0 Unported (CC BY-NC-ND4.0) License. To view a copy of this license, visit http://creativecommons.org/licenses/by-nc-nd/4.0/ or send a letter to Creative Commons, PO Box 1866, Mountain View, CA 94042, USA.

Publisher's Note: The content of this publication does not necessarily reflect the views or policies of the publisher, nor does any mention of trade names, commercial products, or organizations imply endorsement by the publisher. Scientific and legal responsibilities of published manuscript belong to their author(s). The publisher remains neutral with regard to jurisdictional claims in published maps and institutional affiliations. 